\title{
THE SIGNIFICANCE OF INDIVIDUAL CONTRIBUTIONS IN AMATEUR ART PROCESS IN LATVIA
}

Baiba Tjarve ${ }^{1}$, Dr.art./ Researcher; Ieva Zemite², Dr.oec./ Researcher, lecturer and

Kristine Freiberga ${ }^{3}$, Mg.art./ Researcher

$1,2,3$ Latvian Academy of Culture

\begin{abstract}
The proposed article takes a closer look at economic factors that are crucial for the development of the Song and Dance Celebration in a long-term. Individual contributions of amateur artists are essential for sustaining the tradition because of several reasons. Firstly, amateur arts in its essence are oriented at selfinitiative. Therefore, certain financial responsibility should be taken at the lowest, individual level. Secondly, as amateur art in Latvia is strongly supported by the public authorities, stronger emphasis on individual contributions is a way to share risks and strengthen diversity of funding sources, which is especially significant in the context of negative demographic tendencies and uncertainty of economic developments.

Quantitative survey of amateur artists in 11 municipalities and 4 focus group discussions were conducted. The survey results confirm the opinions expressed in the focus group discussions that the amateur art community in Latvia is not ready to increase their financial contributions for participatory activities. In their opinion, public funding should cover costs for rehearsal venue, salary of the leader of the amateur art group, transport costs for the tours in Latvia and costs for concert costumes. The key argument is the public responsibility for safeguarding the tradition of the Song and Dance Celebration. The participants are willing to finance by themselves informal events and participation fee that covers small everyday expenses. The authors can assume that participants feel comfortable with and can justify such expenditure that increases their social capital and strengthens their belonging to the community (amateur choir or dance group).
\end{abstract}

Key words: amateur arts, participation in arts, individual contributions, funding for amateur arts, public funding.

JEL code: $Z 10$

\section{Introduction}

Active participation in culture is a widespread leisure time activity in Latvia, a survey suggests that about half of Latvian inhabitants have taken an active part in one or several cultural activities, including amateur arts (Culturelab, 2016). The residents of Latvia rather often identify a word 'culture' with the Song and Dance Celebration (Culturelab, 2014); moreover, those who take part in amateur art activities, often prefer activities which form the process of the Song and Dance Celebration, a tradition which is unique for all three Baltic states and was inscribed on the Representative List of the Intangible Cultural Heritage of Humanity by UNESCO in 2008.

The current study is a part of the national research programme "Habitus: Sustainability of Latvian Cultural Traditions in an Innovative Environment", which is carried out by the Latvian Academy of Culture. The overall aim of the programme is to define preconditions of safeguarding and criteria for continuity of Latvian national identity forming traditions in a changing and innovative environment. The proposed article takes a closer look at economic factors that are crucial for the development of the tradition of the Song and Dance Celebration in a long-term. Authors presume that individual contributions of amateur artists are essential for sustaining the tradition of the Song and Dance Celebration in future because of several reasons. Firstly, amateur arts in its essence are oriented at self-initiative and bottom-up activities. Therefore, certain financial responsibility should be taken at the lowest, individual level. Secondly, as amateur art in Latvia is strongly supported by the public authorities and institutionalised (Tjarve et al., 2017a, 2017b), stronger emphasis on individual contributions is a way to share risks and strengthen diversity of funding sources, which is especially significant in the context of negative demographic tendencies and uncertainty of economic development. 
The specific aim of the article is to assess whether and on what extent the individual contributions are significant for amateur arts in Latvia and particularly for those artistic groups which maintain the process of Song and Dance Celebration (choirs and dance groups). Authors have set several tasks: 1) to study theoretical literature to understand whether and why individual contributions are significant in amateur arts sector in general; 2) to analyse the situation in Latvia and data regarding choirs and dance groups in Latvia, paying more particular attention at what kind of costs individual amateur artists contribute, which budget categories they are willing to cover, or which they consider to be covered by other actors, including public authorities; what their understanding of the need for individual contributions is; 3 ) to conclude whether individual contributions for amateur arts in Latvia are significant, or not.

Usually the amateur arts are being analysed in the discourse of social impact, social functions and as a tool for social and cultural capital (Matarasso, 1997). Financial aspects of amateur arts are less often in the centre of academic discussions (Tjarve et al., 2017a). Along with the growing significance of participation in arts and amateur art in Europe, it is timely and meaningful to analyse the sustainability factors in regards to financial preconditions of amateur arts. The previous studies of the authors (Tjarve et al., 2017a, 2017b) show that although the division of competences between the state and local governments meets the principles of decentralisation, strengthening the non-governmental sector and individual financial contributions would increase the level of decentralization and foster sustainability of the amateur arts sector and the tradition of the Song and Dance Celebration in a long-term.

\section{Research results and discussion}

\section{Theoretical discussion}

There is a tradition to look at amateur art as a non-paid work (Tsipursky, 2016). For the most part, amateur groups are self-financed, have no paid employees, and only part of the participants are trained professionally, or have worked as professionals (Hill et al., 2018). However, they are indirect beneficiaries from local and state government support, because their activities have been supported by cultural centres providing rehearsal venues and organising concerts, publicity, paying to professional trainers and many more (Milling et al., 2014). Their primary motive for coming together is to have fun and, often to protect what they see as a lost, or dying art form (Hill et al., 2018). As amateur art participants cannot measure benefits they gain from this good in monetary terms (Throsby, 2003), it is also hard for them to justify the necessity for individual's contributions.

Authors have already discussed the role of public incentives for amateur arts in Europe and in Latvia. The classification of fiscal measures proposed by Throsby (2010) included the following categories: (1) direct provision of cultural goods and services; (2) subsidies and grants to cultural producers; (3) tax concessions; and (4) assistance to consumers. The results of analysis showed that subsidies and grants to cultural producers was the most common form of financial support in the field of amateur art in Europe and in Latvia. Direct provision of cultural goods and services was mainly characteristic to post-soviet countries. Meanwhile, tax concessions and assistance to consumers were rather uncommon forms of financial incentives in European amateur art field (Tjarve et al., 2017a). Increasingly amateur arts in Europe are supported through different support mechanisms (Villarroya et al., 2015). As the review on the cultural policies in Europe clearly demonstrates, participation in amateur art activities is not only financed through individual 
contributions for individuals' leisure time activities, but is heavily supported through different public incentives (Tjarve et al., 2017a).

\section{Methodology}

Both quantitative and qualitative research methods have been applied.

For the purpose of this study, a quantitative survey of amateur artists on their individual expenditure in 2015 and 2016 has been carried out between April and June 2017, based on multidimensional survey design. Authors have selected 11 municipalities that represented different types according to the division presented in the Annex 3 to Cultural Policy Guidelines 2014-2020 "Creative Latvia" (Ministry of Culture, 2014): (1) centre of international level (the city of Liepaja); (2) national development centre (the cities of Jekabpils, Jūumala and Jelgava); (3) regional development centre (the municipalities of Kuldiga, Valka, Ludza, Aluksne, Cesis, Balvi and Tukums). In these municipalities from 144 amateur art groups that take part in the process of the Song and Dance Celebration, 36 groups were chosen (both choirs and dance groups, representing different types and generations), and participants during rehearsals were asked to fill in selfadministered questionnaires. 569 responses were received.

Also, focus group discussions "Nationwide Song and Dance Celebration: problems and future scenarios" (Research Centre of Latvian Academy of Culture, 2015) were conducted in each of four cultural regions of Latvia, specifically in towns of Kuldiga (25 September 2015, six respondents), Rezekne (11 November 2015, ten respondents), Jelgava (18 September 2015, nine respondents) and Valmiera (2 October 2015, six respondents).

\section{Description of the situation}

In Latvia, there are 69.6 thousand amateur artists who are taking part in different amateur art groups: they dance, sing in choirs, make theatre or come together to knit or weave. They form $3.4 \%$ of the total number of inhabitants in Latvia in 2016 (Central Statistical Bureau, 2018). Majority of these amateur artists sustain the tradition of the Nationwide Song and Dance Celebration in Latvia. The largest and the most significant groups are choirs and folk dance groups, which acquire common repertoire and are exposed to certain quality inspection in order to qualify for taking part in the final events of the Song and Dance Celebration in Riga.

Even though in many other countries amateur art groups are self-governed, in Latvia the process is rather institutionalised, mainly due to the organisation of amateur art sector during the Soviet period (Daugavietis, 2015) and also due to the complicated organisational process which involves numerous and diverse stakeholders. There are several fiscal support mechanisms both on national and local level that sustain the tradition of Song and Dance Celebration in Latvia (Tjarve et al., 2017a).

Those amateur arts groups, which are established by the local authorities, are mostly located at the culture centres, which operate under the jurisdiction of municipalities; therefore, they have direct administrative and financial support and are publicly owned and operated. The survey of the leaders of the amateur art groups (Research Centre of the Latvian Academy Culture, 2014) shows that $78 \%$ of amateur art groups are established by the local municipalities. Just some of the amateur art groups operate as non-governmental organizations established by their participants, self-financed and independent. 


\section{The results of the participant survey}

The data collected from the survey of 569 representatives of choirs and dance groups in 11 municipalities allow evaluating the actual expenses of individuals in 2015 and 2016 and their opinion about the funding model of amateur arts.

Questions about personal expenses in the survey have been divided in two categories: regular (monthly) and occasional (few times a year) expenses. Regular expenses include (1) participation fee; (2) travel costs to attend the rehearsals; (3) costs for renting the rehearsal venue; (4) costs for paying the salary of the artistic leader. The results show that respondents of all 36 artistic groups don't have to pay for the rent of the rehearsal venue or the salary of the artistic leader. The average expenses to cover the participation fee are EUR 3.02 per month (excluding extreme values). $61 \%$ of the respondents have stated they have travel expenses to attend the rehearsals. The travel costs vary from EUR 1.50 to EUR 150. Due to the wide range of the results it is impossible to calculate the average travel expenses per participant. The respondents have also mentioned several examples of 'Other regular expenses', for instance, presents; flowers; souvenirs; clothing and accessories; dry-cleaning; shoes and their repairing; cosmetics; hairdresser before every concert; tights; water; chewing gum; food, alcohol for informal events; excursions; renting the warehouse; printing posters; buying props; permit for entering Jurmala city; physiotherapy; remuneration for choreographer; traffic fines; as well as alternative costs for not attending the work or finding the substitute at work. Some of these expenses might be counted as the occasional ones, but due to the methodology chosen it is impossible to verify that. The results show that regular expenses per month vary from EUR 0.70 to EUR 97 (excluding extreme values). The total regular expenses of the respondents might be classified in five groups (Table 1) with EUR $0.01-5.00$ and EUR $10.01-20.00$ being the most common amplitudes.

Total regular expenses per month, regarding participation

Table 1 in the amateur art group

\begin{tabular}{|l|c|}
\hline & Total \\
\hline EUR 0.01 - 5.00 & $28 \%$ \\
\hline EUR 5.01 - 10.00 & $13 \%$ \\
\hline EUR 10.01 - 20.00 & $28 \%$ \\
\hline EUR 20.01 - 35.00 & $20 \%$ \\
\hline > EUR 35.01 & $11 \%$ \\
\hline
\end{tabular}

Source: authors' calculations based on the survey of amateur art groups participants, 2017, $n=522$

Questions about occasional expenses included (1) travel expenses to concerts and events in Latvia; (2) travel expenses to concerts and events abroad; (3) informal events; (4) clothing for rehearsals; (5) concert costumes. Responses in the category 'Other occasional expenses' included presents; flowers; cosmetics; food and drinks; participation fees in the events; printing and buying musical scores; buying folders for scores; buying books and CDs. Data show that the occasional expenses cover wide range - from EUR 1 to EUR 1620 per year in 2015 and from EUR 1 to EUR 1450 per year in 2016. Such a diversity makes it difficult to calculate the average costs per year. Data show that the occasional expenses vary a lot according to the activities of the artistic group and its plans for the season: number of concerts, tours, participation in events in Latvia and especially - going for an international tour. The question about buying clothing for rehearsals is topical only for respondents from the dance groups. The concert costumes for artistic group are usually purchased for a longer period of time. The authors observed that the most 
common expenditure in the category 'occasional expenses' is 'expenses for informal events' (food, drinks and alcohol). In $201577 \%$ and in $201686 \%$ of the respondents have indicated that they have had expenses in this category (averagely - EUR 39.81 per year in 2015 and EUR 44.33 in 2016).

The survey results allow calculating the approximate total expenses regarding participation in amateur art group per year. Total expenses have been calculated based on regular monthly expenses (based on the last full month before the survey in spring 2017) and occasional expenses in 2016. It should be taken into account that the calculations are made about different years. For calculating regular expenses per year the average sum of monthly expenses was multiplied by 10 (months), assuming it as a length of artistic season. The sum obtained was summed with the average occasional expenses in 2016. The calculations show that respondents have had expenses from EUR 3.00 to EUR 2100.00 per year regarding their participation in amateur arts activities. As it can be seen, the expenditure forming models can be different; that's why actual average sums cannot be calculated. In Table 2, the total average expenses per year are arranged in five almost equal groups. The differences between dance groups and choirs can be observed.

Total expenses per year, regarding participation in the amateur art group

\begin{tabular}{|l|c|c|c|}
\hline & Total & Dance groups & Choirs \\
\hline < 50.00 EUR & $12 \%$ & $7 \%$ & $20 \%$ \\
\hline EUR 50.01 - 150.00 & $23 \%$ & $18 \%$ & $31 \%$ \\
\hline EUR 150.01 - 250.00 & $23 \%$ & $21 \%$ & $27 \%$ \\
\hline EUR 250.01 - 500.00 & $24 \%$ & $28 \%$ & $18 \%$ \\
\hline > 500.01 EUR & $18 \%$ & $26 \%$ & $4 \%$ \\
\hline
\end{tabular}

Most of the members of dance groups spend more than EUR 250 per year. Largest part of the choir members spends less: between EUR 50 and EUR 250 per year. Yet, the authors cannot make any further interpretation of data.

The other part of questions in the survey discussed the opinions of the participants and their willingness to pay for the participatory activities. The respondents were asked to choose who should finance the expenses for the participation in the amateur art group - the state, the municipality, the participants themselves, or the expenses should be shared. The results show that the respondents are willing to pay for those categories of expenses they are actually paying - the expenses for informal events (66\%), participation fee (54\%), and travel expenses to and from rehearsals $(46 \%)$. The responses show that expenses for renting the rehearsal space $(92 \%)$, expenses for the salary of the artistic leader of the group ( $88 \%)$, travel expenses to the concerts in Latvia (77\%) and expenses for the concert costumes (67\%) in the opinion of amateur artists should be financed by the state and/or municipality. The most controversial question was about financing the clothing/costumes for rehearsals - opinions were almost equally divided between all the options, and only $17 \%$ agreed that this should be provided by the participant him/herself.

When asked to what extent the expenses of the group should be financed by the participants themselves, the tendency shows that $66 \%$ of the participants are ready to pay up to one third from the total expenses (Figure 1 ) and only $1 \%$ claims that all the expenses should be covered by participants themselves. 


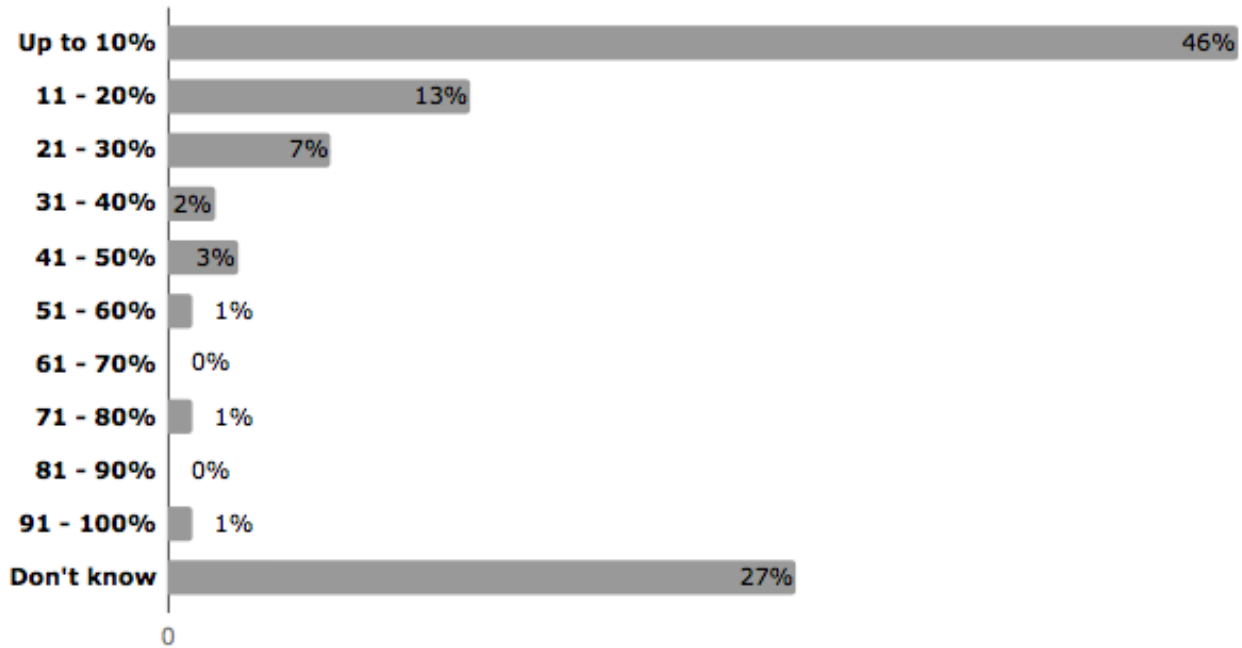

Source: authors' calculations based on the survey of amateur art groups participants, $2017, n=569$

Fig. 1. To what extent respondents would be willing to individually contribute for their participation in the amateur art

These results confirm the results of the focus group discussions (Research Centre of the Latvian Academy of Culture, 2015) that majority of participants in amateur art activities in Latvia do not support the need to co-finance their participation in amateur art activities. For the most part, it is perceived as an obligation of the state and municipalities (validating this statement with an argument of the Song and Dance Celebration being a national tradition that should be safeguarded by public authorities). The participants are not willing to pay for the central expenses, such as the rent of the rehearsal venue or the salary of the artistic leader.

Meanwhile, the results of the survey show that in most cases limited financial resources of individuals have not been an obstacle for participation in the group activities. $54 \%$ of the respondents admit that their activities have not been hindered by the financial barrier. $24 \%$ admit that due to financial reasons they haven't participated in the amateur art group activities abroad.

To conclude, the results of the survey suggest that participants from the dance groups, youth amateur art groups and amateur artists in larger cities spend more than their peers in choirs, in groups from smaller municipalities and in middle generation or senior groups. That can be explained by the specific needs of the dance groups in comparison to choirs and by more enthusiastic participation in diverse events by younger generation that increases the level of individual contributions. Moreover, the correlation between the income and the expenses of an individual can be also observed, as members with higher average income per household member per month tend to spend more for their participatory activities. The survey results confirm the opinions expressed in the focus group discussions that the amateur art community in Latvia is not ready to increase their financial contributions for participatory (leisure time) activities. In the opinion of both, the survey respondents and the focus group discussion participants, public funding (on national or municipal level) should cover costs for rehearsal venue, salary of the leader of the amateur art group, transport costs for participation in the events/tours in Latvia and costs for concert costumes. The key argument is the public responsibility for safeguarding the tradition of the Song and Dance Celebration. In general state and municipal funding covers all the basic needs of the amateur art groups and formally the groups could exist without any individual financial contributions at all. Despite that the participants are willing to finance by themselves the informal 
events and participation fee that covers small everyday expenses (flowers, presents etc.). The authors can assume that participants feel comfortable with and can justify such expenditure that improves the social climate and strengthens their belonging to the group. The respondents also shared the viewpoint that small individual financial contributions are necessary to increase the level of responsibility of an individual towards the group. Further research about social impact of the individual contributions might be applied in the future.

\section{Conclusions, proposals, recommendations}

1) Even though the public (state and municipal) funding is essential and forms the considerable part of the funding for amateur art movement in Latvia (Tjarve et. al., 2017b), findings show that strengthening the non-governmental sector and individual financial contributions would foster sustainability of the amateur arts sector in a long-term. Firstly, amateur arts in its essence are oriented at self-initiative and bottom-up activities. Therefore, certain financial responsibility should be taken at the lowest, individual level. Secondly, as amateur art in Latvia is strongly supported by public authorities and institutionalised, stronger emphasis on individual contributions is a way to share risks and strengthen diversity of funding sources, which is especially significant in the context of negative demographic tendencies and uncertainty of economic developments.

2) Majority of participants in amateur art activities in Latvia do not support the need to co-finance their participation in amateur art activities. For the most part, it is perceived as an obligation of the state and municipalities (validating this statement with an argument of the Song and Dance Celebration being a national tradition that should be safeguarded by public authorities). The participants are not willing to pay for the central expenses, such as the rent of the rehearsal venue or the salary of the artistic leader. In the opinion of both, the survey respondents and the focus group discussion participants, public funding (on national or municipal level) should cover costs for rehearsal venue, salary of the leader of the amateur art group, transport costs for participation in the events/tours in Latvia and costs for concert costumes. This covers all the basic needs of the amateur art group. The participants are willing to finance by themselves the following categories: informal events and participation fee that covers small everyday expenses (flowers, presents etc.).

3) The results of the survey show that participants from the dance groups, youth amateur art groups and amateur artists in larger cities spend more than their peers in choirs, in groups from smaller municipalities and in middle generation or senior groups.

4) In most cases limited financial resources of individuals have not been an obstacle for participation in the group activities. $54 \%$ of the respondents say that their activities have not been hindered by the financial barrier. $24 \%$ admit that due to financial reasons they haven't participated in the amateur art group activities abroad.

5) The authors can assume that participants feel comfortable with and can justify such expenditure that improves the social climate and strengthens their belonging to the group. The respondents also shared the viewpoint that small individual financial contributions are necessary to increase the level of responsibility of an individual towards the group. 


\section{Bibliography}

1. Central Statistical Bureau of Latvia. 2016. Culture Centres at the End of the Year. Retrieved: http://data.csb.gov.Iv/pxweb/Iv/Sociala/Sociala_ikgad_kultura/?tablelist=true\&rxid=cdcb978c-22b0416a-aacc-aa650d3e2ce0. Access: 02.02.2018.

2. Culturelab (2014). Cultural Consumption and Participation of Latvian Population in Cultural Activities 20072014. Riga: Culturelab. Retrieved: https://culturelablv.files.wordpress.com/2014/12/kulturas-paterins-webversija-3-decembris.pdf. Access: 02.02.2018.

3. Culturelab (2016). Cultural audience in Latvia: situation, processes, tendencies. Riga: Culturelab. Retrieved: https://culturelablv.files.wordpress.com/2017/01/kultc5abras-auditorija-latvijc481-2016.pdf. Access: 02.02.2018.

4. Daugavietis, J. (2015). Amateur Arts in Latvia: Community Development and Cultural Policy. Doctoral thesis submitted for the degree of the doctor degree in sociology. Riga: University of Latvia.

5. Hill, L., O'Sullivan, C., O'Sullivan, T., Whitehead, B. (2018). Creative Arts Marketing. Routledge, NY.

6. Matarasso, F. (1997). Use or Ornament? The Social Impact of Participation in the Arts. Stroud: Comedia.

7. Milling, J., McCabe, A., Simpson, R., Fyfe, H. (2014). Cultural Value. Understanding Cultural Value: The Amateur and Voluntary Arts. Retrieved:

https://www.birmingham.ac.uk/generic/tsrc/documents/tsrc/reports/EW-Milling---Expert-Workshop-onAmateur-and-Voluntary-Arts.pdf Access: 02.02.2018.

8. The Cabinet of Ministers (2015). Procedures by which State Earmarked Grant are to be Granted to Local Governments for work remuneration of group leaders and payment of social tax [Kartiba, kada pasvaldibam aprekina un sadala valsts budzeta merkdotaciju maksliniecisko kolektivu vaditaju darba samaksai un valsts socialas apdrosinasanas obligatajam iemaksam]. Regulation Nr. 649. Retrieved: https://likumi.Iv/ta/id/277919-kartiba-kada-pasvaldibam-aprekina-un-sadala-valsts-budzeta-merkdotacijumaksliniecisko-kolektivu-vaditaju-darba-samaksai-un-val.... Access: 02.02.2018.

9. Ministry of Culture of the Republic of Latvia (2014). Cultural Policy Guidelines 2014 - 2020 "Creative Latvia". Translated by State Language Centre. Retrieved:

https://www.km.gov.Iv/uploads/ckeditor/files/KM_dokumenti/CULTURAL_POLICY_GUIDELINES_20142020_CREATIVE_LATVIA.pdf Access: 02.02.2018.

10. Research Centre of the Latvian Academy of Culture (2014). Electronic Survey of Leaders of Amateur Arts Groups (111 respondents, September, 2014).

11. Research centre of the Latvian Academy of Culture (2015). Focus groups "Nationwide Song and Dance Celebration: problems and future scenarios". Jelgava Focus group discussion September 18, 2015 (9 respondents); Valmiera Focus group discussion October 2, 2015 (6 respondents); Kuldiga Focus group discussion September 25, 2015 (6 respondents); Rezekne Focus group discussion November 11, 2015 (10 respondents).

12. Research Centre of the Latvian Academy of Culture (2017d). The Survey about the Financial Contribution of the Participants Regarding the Participation in Choirs and Folk Dance Groups in 11 Municipalities.

13. The Saeima (1994). The Law "On Local Governments". Retrieved: https://likumi.Iv/ta/en/id/57255-on-localgovernments. Access: 02.02.2018.

14. The Saeima (2005). Song and Dance Celebration Law. Retrieved: https://likumi.lv/ta/en/id/111203-songand-dance-celebration-law. Access: 02.02.2018.

15. The Saeima (2015). The Law On Local Governments Finance Equalization [Pasvaldibu finansu izlidzinasanas likums]. Retrieved: https://likumi.Iv/doc.php?id=274742. Access: 02.02.2018.

16. Throsby, D. (2010). The Economics of Cultural Policy. Cambridge, UK: Cambridge University Press.

17. Throsby, D. (2003). Determing the Value of Cultural Goods: How Much (or How Little) Does Contingent Valuation Tell Us? Journal of Cultural Economics, Volume 27, pp. 275-285.

18. Tsipursky, G. (2016). Socialist Fun: Youth, Consumption and State-Sponsored Popular Culture in the Soviet Union, 1945- 1970. University of Pittsburg Press.

19. Tjarve, B., Zemite, I., Freiberga, K. (2017a). Rethinking the Role of Public Incentives for Amateur Arts. The International Journal of Interdisciplinary Cultural Studies, Volume 12, Issue 1, pp. 1 - 13. Retrieved: http://ijicst.cgpublisher.com/product/pub.268/prod.97. Access: 02.02.2018.

20. Tjarve, B., Zemite, I., Freiberga, K. (2017b). Fiscal Decentralisation in Amateur Art Sector in Latvia. TRAMES, Volume 21, Issue 4, pp. 383-402. Retrieved:

http://www.kirj.ee/public/trames_pdf/2017/issue_4/Trames-2017-4-383-402.pdf. Access: 02.02.2018.

21. Villarroya, A., Ateca-Amestoy, V. (2015). Council of Europe/ERICarts: "Compendium of Cultural Policies and Trends in. Europe", 17th edition 2015. 